IZA DP No. 9385

Disentangling the Role of Contract Types and Sector Disparities for Public Service Motivation

Christian Grund

Kirsten Thommes

September 2015 


\title{
Disentangling the Role of Contract Types and Sector Disparities for Public Service Motivation
}

\author{
Christian Grund \\ RWTH Aachen University \\ and IZA \\ Kirsten Thommes \\ RWTH Aachen University
}
Discussion Paper No. 9385
September 2015

\author{
IZA \\ P.O. Box 7240 \\ 53072 Bonn \\ Germany \\ Phone: +49-228-3894-0 \\ Fax: +49-228-3894-180 \\ E-mail: iza@iza.org
}

\begin{abstract}
Any opinions expressed here are those of the author(s) and not those of IZA. Research published in this series may include views on policy, but the institute itself takes no institutional policy positions. The IZA research network is committed to the IZA Guiding Principles of Research Integrity.

The Institute for the Study of Labor (IZA) in Bonn is a local and virtual international research center and a place of communication between science, politics and business. IZA is an independent nonprofit organization supported by Deutsche Post Foundation. The center is associated with the University of Bonn and offers a stimulating research environment through its international network, workshops and conferences, data service, project support, research visits and doctoral program. IZA engages in (i) original and internationally competitive research in all fields of labor economics, (ii) development of policy concepts, and (iii) dissemination of research results and concepts to the interested public.
\end{abstract}

IZA Discussion Papers often represent preliminary work and are circulated to encourage discussion. Citation of such a paper should account for its provisional character. A revised version may be available directly from the author. 
IZA Discussion Paper No. 9385

September 2015

\section{ABSTRACT}

\section{Disentangling the Role of Contract Types and Sector Disparities for Public Service Motivation}

The intention of "doing good for society" is regarded to be a crucial motivator for employees in the public sector in order for them to perform well. Recent research in the public sector literature calls for a deeper understanding of how this specific public service motivation (PSM) is shaped. In our paper, we analyze how different degrees of inclusion in the public sector impact PSM. We also investigate how prospects of employment relations (fixed-term versus permanent contracts), temporal differences (part-time versus full-time employment), and actual jobs (core versus subsidiary jobs) moderate PSM in public service. Our findings show that aspects of PSM are affected by these employment characteristics in various ways, suggesting that the factors influencing PSM are multifaceted and that actual employment conditions have to be taken into consideration when assessing PSM.

JEL Classification: M55, J45, H83

Keywords: $\quad$ job characteristics, motivation, PSM, public sector, part-time, temporary employment

Corresponding author:

Christian Grund

RWTH Aachen University

Chair of Human Resource Management and Personnel Economics

Templergraben 64

52056 Aachen

Germany

E-mail: christian.grund@rwth-aachen.de 


\section{Introduction}

As the public sector plays an important role for society, employees' public service motivation (PSM) is of crucial interest: In the past, several attempts were undertaken in order to define an individual's inclination to be employed in the public sector. Basically, most definitions include individual motives to serve society and to act in the public interest. PSM is therefore defined as "motives and actions in the public domain that are intended to do good for others and shape the well-being of society" (Perry and Hondeghem 2008a: 3; see also Rainey and Steinbauer 1999: 23; Perry and Hondeghem 2008b). The link between PSM and public sector employment is frequently examined in the way in which PSM might result in sorting into the public sector (Georgellis, Iossa, Tabvuma, 2011; Leisink and Steijn 2008; Vandenabeele 2008; Wright and Christensen 2010) or might result from socialization in the work-place (Kjeldsen and Jacobson, 2012; Lewis and Frank 2002; Steijn 2008; Tschirhart et al. 2008). Either way, individuals in the public sector need motivation to do well for others and to shape the well-being of society. They are frequently found to be motivated differently compared to private sector employees, and the magnitude of PSM significantly impacts performance in the public sector (e.g. Houston, 2000; Houston, 2006; Buelens and Van den Broeck, 2007, Moynihan, 2012).

However, recent research in the public administration literature suggests that not all employees of the public sector are equally interested in serving the public. Instead, PSM depends on the institutional environment, and research at this intersection is needed (Coggburn, 2001; Perry, et al., 2010: 685; Moynihan et al., 2013). Actual working conditions might matter for PSM, as they determine the actual scope of serving the public in a job. Although some literature stresses that employment characteristics in the public sector matter for motivation and commitment (e.g. Conley, 2002; Jalonen et al., 2006) and that the causal effects from workplace conditions on motivation might even fundamentally differ from those of private sector 
employment (e.g. Mocan and Tekin, 2003; Thorsteinson, 2003), there is no research up till now which systematically addresses the effect of employment characteristics on PSM.

In our paper, we address three job characteristics apart from variation across industries in particular. These characteristics are (1) the temporal duration of a job, i.e. temporary or permanent contracts, (2) the working hours (part-time versus full-time), and (3) the specific content of a job (core or support). We argue that all these characteristics impact the scope of "serving the public" at work and contribute to the debate whether selection or socialization affect PSM.

We aim to quantitatively assess the link between these job characteristics and PSM from an employee perspective. Taking two important dimensions of PSM into account, i.e. employee attitudes towards engagement for others and being politically and/or socially involved, we use the German Socio Economic Panel (GSOEP) in order to assess to what extent job characteristics are related to PSM. In our paper, we systematically address the following research questions:

Can we confirm systematic differences between public- and private-sector employees with respect to PSM? Is there a relation between temporary as well as part-time work and PSM - in particular for employees in the public sector? How do changes in working conditions affect PSM? To what extent do we find inter-industry differences within the public sector and differences between occupations within certain industries?

Insights with regard to these questions are very important in order to provide contextspecific arrangements for effective management of employee recruiting, retention, and motivation. The remainder of our contribution is organized as follows: We start by deriving hypotheses with respect to the relation between specific job characteristics and PSM based on arguments of core-periphery employment models and previous related empirical findings. We introduce our data and variables in section 3 before we present our empirical results in section 4. Section 5 concludes. 


\section{Core-Periphery Employment Models}

The baseline hypothesis of this paper is that PSM is more prevalent among employees in the public sector. Convincing empirical evidence for this relation has emerged (e.g. Perry and Hondeghem 2008a) since it was first discussed by Perry and Wise (1990). We follow existing research by first assuming that:

\section{Hypothesis 1: Employees in the public sector show higher levels of PSM than employees in the private sector do.}

However, it may well be the case that PSM is not equally high in all jobs, but also that it depends on working conditions. The notion that actual work and their actual working conditions matter for employees' motives as well as work outcomes is well established in Human Resource Management (HRM) research (e.g. Barker and Christensen, 1998; Stamper and Masterson, 2002). Frequently, researcher apply a core-periphery model of employment status (Kalleberg et al. 2000; Kalleberg 2000), describing how firms establish a flexible periphery of workers around a solid core of employees in order to increase their numerical and functional flexibility. The flexible peripheral employment relation is usually defined as temporal flexibility, such as part-time or temporary work, while the stable core consists of long-term and full-time employees. The idea of differentiating between employees in the core and on the periphery of an organization is not only useful for explaining employee motivation in private organizations, but can also be transferred to employees in the public sector: Organizational commitment can suffer, if employees face high levels of job insecurity, (e.g. De Witte and Näswall, 2003; Eberhardt and Moser, 2011). Commitment in turn is the most relevant predictor for motivation in general (Moynihan and Pandey, 2007; Battistelli et al., 2013) and also significantly correlates with PSM (Potipiroon and Ford, 2014). 
HRM literature on motivation, however, does not only stress an employee's job in the core or on the periphery as relevant, but also the job itself. Job Characteristics Theory (Hackman and Oldham, 1975; Oldham and Hackman, 1981), for instance, assumes that job characteristics impact motivational attitudes of employees. In the very first research on job characteristics, Hackman and Oldham (1975) particularly stress the social dimensions of work, highlighting that especially the degree of interaction by others and social approval from others impact work motivation (see also Grant and Parker, 2009). Recent research on the public sector seems to confirm this seminal idea by stratifying jobs in the public sector according to the degree of interaction with the public (Christensen and Wright, 2011) as PSM might be reinforced when interacting with the public.

However, the question arises as to whether employment relations at the periphery of an organization have the same impact in public as in private firms. Transferred to the concept of PSM, not only temporary and part-time work can be viewed as peripheral employment modes, but also jobs in the public sector in which employees do not directly interact with the public and do not receive direct feedback from the public, either. We therefore propose three dimensions of core-periphery employment modes which might be all related to PSM: Temporal duration of the employment contract, working hours (part-time vs. full-time), and job characteristics. In the following, we discuss the potential relevance of these three issues for PSM:

(a) (Expected) contract length and PSM

The deployment of temporary employees in private firms as well as in the public sector is common practice. The share of temporary employees in the EU has remained constant at a high level of about $14 \%$ in the past 20 years and even in the US, the share is at about $7 \%$ despite the labor-at-will employment clause that is in place in most US states (OECD, 2014; Dertouzos 
and Karoly, 1992). Kalleberg (2000) and Summers (1997) suggest also all labor-at-will employees are basically temporary workers in the US, which would in turn imply that the share of temporary workers in the US by far exceeds the average European share. The high number of temporary workers is not only prevalent in the private, but also in the public sector: Conley (2002) shows that temporary work constitutes for about $11 \%$ of all UK employees in the public sector. The Organization for Economic Co-Operation and Development (OECD, 2002) confirms these results by stating that temporary work is becoming increasingly common in the public sector, too, although the public sector seems to tend towards fixed-term contracts with an above-average duration of more than one year.

Past research on the effects of employing people for a limited period of time focuses on private firms and provides mixed findings: Research shows that temporary jobs can serve as a stepping stone towards regular employment, resulting in equal pay and equal unemployment risks in the long-run (Heinrich et al., 2005), that temporary employees might be more willing to exert extraordinary efforts compared to standard employees if the contract is perceived as a probation period (Engellandt and Riphahn, 2005), and that temporary jobs protect permanent employees against dismissals (Bronstein, 1991; Von Hippel et al., 1997). However, other research stresses that temporary workers have to bear negative consequences, such as a reduction in their well-being, lower wages, less training, and a greater likelihood of unemployment (Frey and Stutzer, 2002; Lucas, 2007; De Cuyper et al., 2008; Gagliarducci, 2005; de la Rica, 2004; Booth et al., 2002; Jimeno and Toharia, 1993).

With respect to the public sector and PSM, the question of whether temporary work affects PSM is not yet fully understood. Differences from private sector employment might be expected, for instance, if the take-over probability of a temporary worker is rather small or if unlimited employment contract durations are one of the main benefits of public sector employment. Case studies from some specific public sectors suggest that temporary 
employment might indeed be exceptionally harmful for PSM in the public sector. Conley (2002) shows that in the public education sector, temporary employees seem to suffer extraordinarily from a "state of insecurity" that they are facing through their temporary employment. Conley suggests that the impact of temporary employment contracts on motivation and individual wellbeing might be remarkably high in the public sector and hugely jeopardize PSM. In a longitudinal study of nurses in Finland, Jalonen et al. (2006) analyze the effect of temporary jobs on organizational commitment. After being converted into permanent contract workers, nurses show significantly higher levels of organizational commitment compared to those who remain temporary workers. This relation, however, is mediated by perceived job control, psychological distress, and procedural justice. Since job security plays a much more important role as an incentive for employees in the public sector in Germany than it does in the private sector in general, it is our expectation that:

Hypothesis 2: Temporary contracts negatively moderate the link between employment in the public sector and PSM.

\section{(b) Part-time work and PSM}

Compared to contract length of the job, there is even less research about part-time employment and PSM. This lack of research is especially puzzling, as part-time employment is frequently found in the public sector. Right now, part-time employment constituted about 20 to $25 \%$ of all dependent employment relations in most European countries (OECD, 2013; Kalleberg, 2000). This number seems to be roughly equally high in private and public firms, since Cribb et al. (2014) find that $27 \%$ of all public sector employees in the UK had part-time working arrangements in 2012/2013; the US shows a respective figure of about 20\% (Mayer, 
2014). While some employees have part-time jobs involuntarily, others are in part-time employment on their own request, for instance because they want to take care of others, such as their family, or they are volunteers in order to serve the society (e.g. Kalleberg, 2000; Walsh, 1999, 2007; Bussell and Forbes, 2002).

By definition, part-time employees have less opportunity to interact with their colleagues: social interactions at work are also restricted quality-wise because part-time employees are also highly unlikely to ever be perceived as a regular member in an existing group (O’Neill and Adya, 2007). They are also less likely to share their knowledge (Bartol et al., 2009), and have fewer opportunities to learn on the job (Billett, 2001), or to establish social relations at work (Walsh, 2007) and thus socialization may remain limited. Research on compensation indicates different logics of part-time work when comparing the private and the public sector as part-time employees earn higher hourly wages than full-time employees in the public sector (Leete, 2000; Mocan and Tekin 2003), whereas the opposite is true in the private sector (Hirsch, 2005).

Different logics between public and private sector employment also seem to apply for constructs that are closer to PSM: Part-time employees in the private sector do not seem to differ from their full-time employed colleagues in terms of their attitudes towards their job and employer (Thorsteinson, 2003). In contrast, public sector part-time employees seem to execute less effort than their full-time working colleagues do (Frank and Lewis, 2004) and also have lower levels of job satisfaction (Taylor, 2007) and commitment (Coyle-Shapiro and Kessler, 2003).

This suggests that working hours in the public sector have different consequences than in the private sector. For public organizations in particular, the socialization effect is important: If PSM is formed by socialization on-the-job in a public organization (or is at least reinforced by it), the frequency and quality of interaction at work does matter for the evolution of PSM. 
We, therefore, expect that the relation between public sector employment and PSM is affected by individuals' working hours and formulate:

Hypothesis 3: Part-time work negatively moderates the link between employment in the public sector and PSM.

\section{(c) Job characteristics and PSM}

Past research on PSM and job choice provides mixed findings concerning the question of whether employees with high PSM actively choose to be employed in the public sector (e.g. Tschirhart et al., 2008; Wright and Christensen, 2010). One important finding of current research is that there is not one homogeneous public sector, but different jobs within the public sector so that PSM is assumed to be pronounced to different degrees across areas and jobs of the public sector.

With respect to job characteristics, several different organizations can belong to the public sector, such as hospitals, schools, police force, but also some utilities and financial service firms. As it is reasonable to assume that PSM is not equally important and equally formed across different industries of the public sector, we first see the necessity to analyze PSM in the different sub-industries and to evaluate whether PSM for employees in different subsectors of the public service is exactly as high or exactly as different from private sector employees.

But there might also be differences within industries between certain jobs or occupations. Christensen and Wright (2011) show that the degree of service orientation of a job plays a crucial role for law graduates: Individuals with high levels of PSM do not automatically choose a job in the public sector, but a job with high levels of service orientation. Kjeldsen and 
Jacobsen (2012) confirm this result. They study Danish physiotherapy students and confirm the result that PSM seems to be irrelevant for job choice. However, contrary to employees in the private sector, employees in the public sector can maintain their level of PSM after job entry. This suggests that there seems to be a temporal effect of PSM over time, but not a direct sorting effect. What both past studies have in common is that they highlight the interplay between actual job characteristics and PSM. However, both studies analyze only one specific profession within the public sector. In order to understand the nature of PSM more comprehensively, we need to know the differences between jobs within the public sector and how these differences affect public sector motivation. When extending the case studies to a broader concept, we would expect a difference within each field of the public sector and a distinction between the service side of the public sector and the administrative side of it.

Several distinctions can be made with regard to PSM and the two parts: First, even after the introduction of New Public Management and privatization attempts, a lot of organizations are still owned by the government because they serve the general interest of the public, such as health care, utility supply, or safety and security. For employees serving the public interest in this sense, PSM is crucial (either as a pre-disposition or in order to fulfil the service): Individuals executing the core services of the public organization the "individual value structure and the conduct of the government [...] [is] a critical concern for administrative states where democracy is largely implemented by the bureaucracy" (Perry and Wise, 1990: 372). Individuals executing these jobs often have frequent direct contact with the public as customers and therefore might be likely to satisfy their behavioral motive of service orientation (Perry and Wise, 1990) through the job because they directly serve and interact with the public. On the other hand, they are mostly, by definition, bound to the public organization since most of their professions are usually only employed in the public service. 
On the other hand, every public sector organization also has some supporting employees who are not directly serving the public interest, but only indirectly supporting the public service performed, such as the administrative staff in hospitals, utility firms, or the police force. These employees usually have less contact with the public when performing their job. On the other hand, these administrative employees, such as secretaries, accountants, or office managers have far more outside options and can easily switch to any other job in the private or public sector without endangering their profession-specific human capital.

Accordingly, recent research suggests that PSM might not be compulsorily attached to the sector as an industry, but might more likely be attached to certain jobs, and that jobs might matter more than sector: Vandenabeele (2008) analyzes attractiveness of employers and finds that individuals with high PSM value the public sector if the specific occupation emphasizes direct contact with the public, such as in education or welfare. In other jobs however, PSM is not causally linked to the attractiveness of the public sector. Georgellis, Iossa and Tabvuma (2011) also highlight the importance of distinguishing between different parts of the public sector: Their findings suggest that sorting effects and accompanying, possibly crowding-out effects only occur in the health care sector and in the higher education sector whereas other parts of the public sector might be chosen more likely in account of extrinsic incentives and therefore be less likely to be subject to motivational crowding out. In a controlled experiment with law students, Christensen and Wright (2011) show that PSM did not influence sector choice of employment. Instead, job descriptions in terms of service orientation mattered and individuals showing high levels of PSM were significantly more likely to choose serviceemphasizing jobs - both in the public and in the private sector.

When we compare core jobs of the public sector with support jobs, we might see differences in public sector motivation as well: Support staff with more administrative tasks such as office clerks in hospitals or schools might be less frequently regarded to be serving the 
public interest and have more outside options to other industries compared to professionals in core jobs of the public sector (such as teacher or nurses). We therefore hypothesize:

Hypothesis 4: Core staff in the public sector show higher levels of PSM than support staff do.

\section{(d) Sorting or Sozialization}

So far, our considerations compare possible differences between subjects, e.g. employees within the private sector and the public sector, with temporary and permanent jobs, part-time and full-time as well as in the core function or support staff. In order to shed light on the question whether some job characteristics have been chosen by the employee because of his/her level of PSM or whether PSM was the consequence of certain job characteristics, we also have to compare within subjects after changes in their working conditions. If socialization holds true, employees are supposed to show increases in PSM after switching from an private to an public employer and also corresponding changes in PSM subsequent to changes in contracts.

Taking person fixed effects into account, we can explore, whether individuals are socialized on the job with respect to PSM. If corresponding increases in PSM cannot be observed, PSM might not be due to socialization but rather be a result of self-selection. As we aim to contribute to the current literature on sorting or socialization, we will also investigate whether changes in contracts are associated with changes in PSM

\section{Data, variables, and descriptive statistics}

Data: We make use of the German socio-economic panel (GSOEP), which is a large and rich data set of people living in Germany. The data are provided by the German Institute of 
Economic Research (DIW Berlin). ${ }^{1}$ The GSOEP is a representative longitudinal study of private households. Every year since 1984, about 15,000 households - which are tantamount to about 25,000 individuals - are sampled. Large parts of the questionnaire remain constant over time; however, sometimes new items are included in it. The main topics of the survey include household composition, occupation and employment, earnings, health, and life satisfaction.

We consider full- and part-time working employees aged 18 to 65 years for our study. Unemployed persons as well as individuals in marginal employment (in so called "mini jobs" with a monthly wage of not more than $€ 400$,-) and self-employed persons are excluded from the analysis. This leads to an unbalanced panel with $n=29,445$ observation over the four waves of the GSOEP. In each year, about 30 percent of employees work in the public sector $(n=8,746$ in the whole sample).

Dependent variables: Recent research in PSM suggests that PSM is not one latent construct, but instead composed of different, probably independent dimensions (e.g. Houston, 2011; Ritz, 2011; Kim et al., 2013; Pedersen, 2013; Desmarais and Gamassou, 2014). We follow that line of research and focus on two dimensions, which we will analyze separately. The GSOEP survey includes two questions on aspects of public sector motivation in four particular waves $\left(1995,2004,2008\right.$ and 2012). ${ }^{2}$ Specifically, individuals are asked:

Are the following issues currently "Very important", "important", "less important” or "not important" for you?
1.) Be there for others
2.) Be politically and/or socially involved.

\footnotetext{
${ }^{1}$ Detailed information on the data and the questionnaire can be found at http://www.diw.de/english/soep/29012.html. Wagner et al. (2007) describe main features of the data.

${ }^{2}$ This information is also part of the year 1992. However, the data lack information on temporary contracts for the vast majority of observations in this year, so that we do not take 1992 into consideration.
} 
These two questions focus on different aspects of public sector motivation. The first measure was already used as a proxy for PSM by Dur and Zoutenbier (2013), who equalize PSM and altruism. A comparable measure was also used for a US sample by Lewis and Frank (2002). Several authors claim that also the second item (political and/or social involvement) might serve as a useful proxy for PSM (Kroll and Vogel 2013, Vandenabeele 2009, Bekkers 2005; Moynihan et al., 2013). Further, PSM and public values, such as citizenship participation, are found to be highly overlapping in recent studies (e.g. Coursey et al., 2012; Andersen et al., 2013). As PSM consists of several dimensions, the relevance of relations may differ across dimensions, of course. We will address this issue in our empirical analysis, too; and we will examine "being there for others" and "being politically and/or socially involved" separately.

We argue that both measures might be valid proxies for PSM since they capture two different aspects: The first question places emphasis on the rather immediate environment of the individual, whereas the second is a broader and abstract measure for social attitudes in general. It is therefore interesting, as to whether these specific issues are related to contract type, part-time work, and areas of the public sector in different ways. ${ }^{3}$

Figure 1 shows the distribution of answers concerning the two aspects of PSM. More than 9 of 10 respondents consider engagement for others to be very important or important. This is the case for less than a quarter of individuals concerning political and social involvement. The distributions differ between public and private sector employees. The share of individuals considering engagement for others and political/social involvement to be less important or not important is somewhat lower in the public sector. Differences between sectors are significant for both variables at this bivariate level (two-sample Kolmogorov-Smirnov- tests, $\mathrm{p}<0.001$ ).

\footnotetext{
${ }^{3}$ These two questions certainly do not encompass all aspects of PSM unlike the PSM-scale developed by Kim (2008) does; measures on this scale are unfortunately not available for a large population of employees in the private and the public sector.
} 
[Figure 1 about here]

We want to examine whether these differences are robust when controlling for differences in contract types and socio-demographics. Further, we want to disentangle the differences for subgroups of employees. With regard to contract types, we distinguish employees with temporary and permanent contracts as well as part- and full-time employees. We also control for demographics (gender, age, having children, years of schooling, NonGerman nationals, eastern Germany), health status, and year of the observation. It is likely that these characteristics affect the situation in private life and also attitudes towards PSM dimensions. For example, individuals with children may find it more important to be there for others, whereas people with a poor health status may tend to focus on themselves. Years of schooling may be associated with higher scores in political/social involvement, for instance. ${ }^{4}$ Table 1 provides an overview of descriptive statistics. The fraction of temporary contracts is somewhat higher in the public $(0.11)$ than in the private sector $(0.08)$. The same is true for parttime contracts (0.26 vs. 0.19). Employees in the public and private sector also differ with respect to some demographics. There are more females and fewer non-German nationals in the public sector. Additionally, employees of the public sector have more schooling and are somewhat older.

[Table 1 about here]

\footnotetext{
${ }^{4} \mathrm{We}$ focus on individual characteristics as controls. We checked, however, that results are robust by considering additional job-based controls, such as wage. Wage as a potential control would decrease the number of observations, though (about 3,000 in the case of wage) and is eventually not a very convincing control, as probably not the individual wage, but the household wage and household composition might matter for PSM dimensions. Further, buying power differs tremendously over time and between German regions, so that many other control variables should be also taken into account. As we wanted to focus on differences between individuals, we therefore decided to refrain from wage as a control variable.
} 
We will refer to subsamples with regard to different industries within the public sector and different occupations within industries.

\section{Results}

Since the attitudes towards engagement for others and political/social involvement are measured on an ordinal scale, we apply ordered probit estimations. We consider the panel structure of our data set by estimating random effects models. ${ }^{5}$ Dummies for the incidence of temporary and part-time contracts act as independent variables next to the public sector dummy and demographics. Table 2 shows the results.

Indeed, individuals in the public sector consider engagement for others (Model 1) and political/social involvement (Model 3) to be more important than employees in the private sector do. Attitudes also differ across individuals with different contract types. Taking into account interaction effects in Models 2 and 4, we examine possible moderating roles of contract type on sector differences. Interestingly, we find that the positive public sector effect on being there for others only holds for employees with an unlimited contract, whereas a temporary contract reduces corresponding attitudes for public sector employees in particular. Not surprisingly, the effect of part-time contracts does not differ across sectors, because a part-time contract does not restrict the possibility of taking care for others. However, the positive public sector effect on political/social involvement is reduced for part-time workers. The results are therefore in line with Hypotheses 2 and 3 for certain dimensions of PSM.

\footnotetext{
${ }^{5}$ This and all further results are robust to applying random effects logit and pooled ordered probit estimations.
} 
The results for the other controls reveal that better educated individuals and employees from Western Germany score higher in both PSM dimensions. Further results show that attitudes can indeed differ between dimensions of PSM. Attitudes concerning being there for others are more distinct for females, younger employees, and non-German nationals, whereas males, older workers, and German workers consider political/social involvement to be more important.

[Table 2 about here]

The random effects estimates do not take employment switches of individuals into account. It is a question of whether differences occur because of some kind of sorting effect of individuals with certain traits with respect to engagement for others and political/social involvement or whether these dimensions of PSM are formed by working in a specific environment with a specific type of contract. We, therefore, additionally want to address the question of whether different people self-select to the public sector or whether working in the public sector affects attitudes towards PSM.

As mentioned above, the PSM dimensions have an ordinal scale. We have coded the response options from 1 (not important) to 4 (very important). Positive changes from one survey year to the next then indicate that the PSM is now more important for the individual. Note that we have to be very cautious when interpreting these changes in the importance of PSM dimensions, which are scaled from -3 to $+3 .{ }^{6}$ We have $n=11,458$ observations of individuals with data in two consecutive survey years in our sample (e.g. 2008 and 2012). Four percent switch jobs from the public to the private sector $(n=489)$, and vice versa $(n=442)$, respectively.

\footnotetext{
${ }^{6}$ The qualitative results hold when considering a simplified approach and distinguishing only between increases, stability, and decreases in PSM dimensions.
} 
Changes in reported PSM dimensions by sector change are illustrated in Figure 2. Minor decreases in engagement for others without sector changes reflect the negative age effect presented in Table 2. Notably, changes differ significantly for those who switch sector: Individuals, who change from the private to the public sector report increases to the amount of 0.052 (T-test, $\mathrm{p}=0.041$ ), whereas changes from the public to the private sector lead to decreases of 0.049 on average (T-test, $\mathrm{p}=0.030$. $\mathrm{T}$-test compared to switches from the private to the public sector: $\mathrm{p}=0.008$ ). Differences with respect to political/social involvement go to same direction. They are not statistically significant, though.

[Figure 2 about here]

Corresponding to Figure 2, we report the role of changes in the employment contract (part-time/full.time and temporary/permanent) for changes in PSM dimensions within sectors in Figure 3. Minor differences between the public and the private sector with regard to working hours are not significant. There is one distinct exception, when looking at switches from temporary to permanent contracts. There are considerable increases for engagement for others in the public sector, whereas there are decreases in the private sector (T-Test, $\mathrm{p}=0.005)$.

[Figure 3 about here]

We complement our results of Figures 2 and 3 with corresponding fixed effects estimations (see Table $\mathrm{A}$ in the Appendix). ${ }^{7}$ Possible effects are then identified by intra-person variations

\footnotetext{
${ }^{7}$ Besides, we estimated corresponding OLS and linear random-effects models. The results coincide with the ordered random-effects model. Hence, present differences between the ordered probit random-effects model and the linear fixed-effects model are not driven by the different estimation technique, but by the relevance of
} 
over time. In line with the figures, fixed-effects estimations on engagement for others coincide with random-effects estimates. There are both significant positive coefficients for the public sector dummy and negative coefficients for its interaction with the temporary contract dummy. Employees therefore seem to adapt their (attitudes to) engagement for others accordingly their own situation. Changes in the employment situation are less associated with changes in attitudes to political/social involvement, though. The corresponding fixed-effects estimates are not significant, although there is more variation in reported attitudes for political/social involvement than for engagement for others. Again, we have to stress that an underlying assumption of this linear fixed-effects model consists in equal differences between categories. Since this is not ensured, we have to interpret results very cautiously and avoid interpreting size effects. We cannot offer a clear causal interpretation, either. Changes in the employment relationship may lead to changes in attitudes, or vice versa.

In a next step, we want to investigate possible differences within the public sector as we assume that not all jobs in the public sector equally imply PSM. In order to test hypothesis 4, we first analyze differences between sub-industries of the public sector and second analyze differences within one sub-industry with respect to core and support staff.

(1) The GSOEP includes information for the industry that employees are working in. We distinguish between six areas with a certain relevance for the German public sector: health, education, public administration, finance (including insurance and estates), culture $\&$ sports and transport \& utilities (including telecommunications). ${ }^{8}$ We have $n=7,851$ observation in these areas of the public sector (Figure A in the Appendix reports the corresponding distributions for PSM attitudes). Again, we apply random effects ordered probit models (see Table 3). The

\footnotetext{
unobserved heterogeneity captured by the individual fixed-effects. We also run a model with the change in reported PSM dimensions as the dependent variable, and sector change dummies as independent variables. The results confirm our fixed-effects estimation and can be provided by the authors on request.

${ }^{8}$ Another possibility of a more detailed analysis would be to explore differences between the public and the private sector within certain industries. Results will be provided by the authors on request.
} 
results reveal that PSM is indeed not identical for all areas. Engagement for others is considered most important in health care and education. There are particular attitudes for political/social involvement in the areas of education and culture \& sports. There is too little variation of individuals between industries so that it is not useful to conduct corresponding fixed-effects estimations.

[Table 3 about here]

(2) As mentioned above, we want to distinguish between employees in the core of an area in the public sector and the support staff of individuals having more administrative tasks. Fortunately, the GSOEP contains ISCO information (International Standard Classification of Occupation). A selection is best possible for the health care and the education sector. We consider doctors, pharmacists, psychologists, and nursing staff as working in the core of the health industry. The corresponding core in education consists of teachers, lecturers, and social workers. We now estimate random effect probit models within these two areas of the public sector and examine whether the core of the industry has specific attitudes to PSM (Table 4). We find that core medical staff in the health industry regards engagement for others to be more important than other employees with more administrative tasks does. Differences within education are less pronounced. ${ }^{9}$

[Table 4 about here]

\footnotetext{
${ }^{9}$ There are differences in the distribution concerning political/social involvement at first glance (see Figure B in the Appendix), because individuals in core occupations in education are much better educated than others (mean years of schooling of 16.3 compared to 14.1).
} 
To sum up, we cannot speak for public sector employees in general, but have to distinguish groups with respect to industry and occupation.

\section{Discussion and Conclusion}

To sum up, we provide new evidence on whether and how PSM is associated to and shaped by working conditions by using a large and representative data set, whereas previous work often sticks to one particular occupation. In contrast to other research, we use a longitudinal dataset which enables us not only to analyze differences across working conditions and industries but also to analyze the relation of changes in working conditions on changes in PSM. Our contribution to the literature of PSM is threefold:

(1) As previously suspected by PSM scholars (e.g. Perry et al. 2010; Moynihan et al., 2013), not all employees within the public sector show the same level of PSM. Instead, PSM depends on the actual working conditions. We use insights from the HR literature to contribute to a better understanding of the relevant working conditions. An employee's relation to the organization impacts motive, motivation, and commitment. The core-periphery model differentiates between employees strongly linked to the organization by having unlimited and full-time working contracts on the one hand and employees in the periphery who are not fully integrated as they have either part-time contracts or temporary contracts on the other hand. We apply this model to the public sector and find that contract type moderates the relation between PSM and being employed in the public sector. The incidence of a temporary contract reduces the link to engagement for others. Part-time work reduces the link to political/social involvement. The results of our fixed effects estimations suggest that employees adapt their valuation of "being there for others" depending on their employment situation. This is not the case for political/social 
involvement, so that differences in this dimension may be rather explained by selection decisions of different types of individuals into jobs.

A way forward to further enrich the discussion of core and periphery employees on PSM could be an international comparison: As in some countries, such as in the US, employment-at-will is common, all employees there can be regarded as temporary to some extent. In other countries, such as in most Central European countries, employees are more likely to react sensitively to temporary contracts because predominantly unlimited employment contracts are in use. Employee perception of employment security might therefore differ not only with respect to contract types, but also with respect to the contract type in relation to the national standard. The same differentiation might also hold true for part-time employment: The more common part-time jobs are in a society, the less impact part-time employment might have on PSM. One consequence of this view on PSM and employment relation might be that not only the construct of PSM is subject to national - probably cultural - differences (Kim et al. 2013), but also that the determinants of PSM differ according to employees' perception of their own employment conditions.

(2) Besides the important notion of differences with respect to employment conditions, we also find evidence that PSM differs across different areas of the public sector. Engagement for others is particularly pronounced for the health and the education industry. There are particular attitudes for political/social involvement in the areas education and culture \& sports. Additionally, we observe within-industry differences across occupations in the health care sector. This finding is in line with past research on the self-selection into jobs with high levels of service orientation (Christensen and Wright, 2011; Kjeldsen and Jacobsen, 2012). However, contrary to the past analysis of very specific jobs within very specific industries, we confirm 
this result in a very broad research setting. Our results suggest that the job-specific levels of service orientation within every sub-part of the public sector vary, and therefore different levels of PSM are displayed by the individuals within one subsector of the public service.

(3) Our results confirm that PSM is a multidimensional construct (e.g. Houston, 2011; Ritz, 2011; Kim et al., 2013; Pedersen, 2013; Desmarais and Gamassou, 2014). We also find that the extent of different dimensions of the PSM construct is triggered by different job characteristics. In our setting, we consider two PSM dimensions: Attitudes towards engagement for others focuses on the immediate environment of individuals, whereas political and social involvement considers more general attitudes for the rather "anonymous" society. The institutional settings of a job (temporary or part-time) as well as the specific job characteristics (with respect to sub-industry and specific job content) impact these dimensions in different ways. However, we never find a reverse impact on the two dimensions in the sense that one determinant increases one dimension of PSM while it diminishes the other dimension. Instead, our results suggest that certain characteristics impact one dimension while having no effect on the other dimension. This result does not contradict the validity of PSM in general. However, the results suggest that a separate analysis of the PSM dimensions is needed in order to improve our understanding of PSM.

Our results have several implications for research in public management: First and foremost, our study highlights that motivation to serve the public might not only differ across cultures and languages (Kim et al., 2013), but also along different employment characteristics: While some dimensions such as 'interaction with the public' were already regarded as being of importance, other dimensions, such as employment status have been neglected so far in public 
management research. However, due to the reforms of New Public Management, temporary and part-time jobs have become more common, which in turn affects employees' PSM. Our results stress that especially the individual's tendency of "being there for others" is significantly affected by temporary positions within the public sector, while in turn "political and social interest" of employees in the public sector seems to be affected by part-time work.

Our results have also some implications for the sorting versus socialization debate in public management: While some sub-industries within the public sector seem to attract individuals scoring high on PSM dimensions, other sub-industries - especially if there is a lot of private competition, such as finance for instance, seem to substantially differ. We therefore think that the mixed results with respect to sorting and socialization might well be explained by the sub-industry differences within the public sector. 


\section{References}

Andersen, Lotte Bøgh, Torben Beck Jørgensen, Anne Mette Kjeldsen, Lene Holm Pedersen, and Karsten Vrangbæk. 2013. Public Values and Public Service Motivation Conceptual and Empirical Relationships. In: American Review of Public Administration 43(3): 292-311.

Barker, Kathleen, and Kathleen Christensen (Eds). 1998. Contingent work: American employment relations in transition. Cornell University Press.

Bartol, Kathryn M., Wei Liu, Xiangquan Zeng, and Kelu Wu. 2009. Social Exchange and Knowledge Sharing among Knowledge Workers: The Moderating Role of Perceived Job Security. In: Management and Organization Review 5(2): 223-240.

Battistelli, Adalgisa, et al. 2013. Mindsets of commitment and motivation: interrelationships and contribution to work outcomes. In: The Journal of psychology 147(1): 17-48.

Bekkers, René. 2005. Participation in Voluntary Associations: Relations with Resources Personality, and Political Values. In: Political Psychology 26(3): 439-454.

Billett, Stephen. 2001. Learning through work: workplace affordances and individual engagement. In: Journal of Workplace Learning 13(5): 209-214.

Booth, Alison L., Marco Francesconi, and Jeff Frank. 2002. Temporary Jobs: Stepping Stones or Dead Ends? In: Economic Journal 112 (418): F189-F213.

Bronstein, Arturo S. 1991. Temporary Work in Western Europe: Threat or Complement to Permanent Employment. In: International Labour Review 130 (3): 291-310.

Buelens, Marc, and Herman Van den Broeck. 2007. An Analysis of Differences in Work Motivation between Public and Private Sector Organizations. In: Public Administration Review 67(1): 65-74.

Bussell, Helen, and Deborah Forbes. 2002. Understanding the volunteer market: The what, where, who and why of volunteering. In: International Journal of Nonprofit and Voluntary Sector Marketing 7(3): 244-257.

Christensen, Robert K., and Bradley E. Wright. 2011. The Effects of Public Service Motivation on Job Choice Decisions: Disentangling the Contributions of PersonOrganization Fit and Person-Job Fit. In: Journal of Public Administration Research and Theory 21(4): 723-743.

Coggburn, Jerrell D. 2001. Personnel Deregulation: Exploring Differences in the American States. In: Journal of Public Administration Research and Theory 11(2): 223-244.

Conley, Hazel. 2002. A state of insecurity: temporary work in the public services. In: Work, Employment \& Society 16(4): 725-737.

Coursey, David, Kaifeng Yang, and Sanjay K. Pandey. 2012. Public service motivation (PSM) and support for citizen participation: A test of Perry and Vandenabeele's reformulation of PSM theory. In: Public Administration Review 72 (4): 572-582. 
Coyle-Shapiro, Jacqueline A-M, and Kessler, Ian. 2003. The employment relationship in the

U.K. public sector: a psychological contract perspective. In: Journal of Public Administration

Research and Theory, 13(2): 213-230

Cribb, Jonathan, Richard Disney, and Luke Sibieta. 2014. The public sector workforce: past, present and future. In: Institute for Fiscal Studies Briefing Note BN145.

De Cuyper, Nele, Jeroen De Jong, Hans De Witte, Kerstin Isaksson, Thomas Rigotti, and René Schalk. 2008. Literature Review of Theory and Research on the Psychological Impact of Temporary Employment: Towards a Conceptual Model. In: International Journal of Management Reviews 10(1): 25-51.

De la Rica, Sara. 2004. Wage gaps between workers with indefinite and fixed-term contracts: The impact of firm and occupational segregation. In: Moneda y crédito: revista de economía 219: 43-69.

De Witte, Hans, and Näswall, Katharina. 2003. Objective'vssubjective'job insecurity: consequences of temporary work for job satisfaction and organizational commitment in four European countries. In: Economic and Industrial Democracy 24(2): 149-188.

Dertouzos, James N., and Lynn A. Karoly. 1992. Labor market responses to employer liability. Santa Monica, Calif.: Rand, 1992.

Desmarais, Céline, and Claire Edey Gamassou. 2014. All motivated by public service? The links between hierarchical position and public service motivation. In: International Review of Administrative Sciences 80(1): 131-150.

Dur, Robert, and Robin Zoutenbier. 2013. Intrinsic motivations of public sector employees: Evidence for Germany. In: SOEPpapers on Multidisciplinary Panel Data Research, No. 623

Eberhardt, Bruce J., and Moser Steven B. 2011. The nature and consequences of part-time work: a test of hypotheses. In: Journal of Applied Business Research 11(3): 101-108.

Engellandt, Axel, and Regina T. Riphahn. 2005. Temporary contracts and employee effort. In: Labour Economics 12(3): 281-299.

Frank, Sue A., and Gregory B. Lewis. 2004. Government employees: Working Hard or Hardly Working? In: American Review of Public Administration 34(1): 36-51.

Frey, Bruno S., and Alois Stutzer. 2002. What Can Economists Learn from Happiness Research? In: Journal of Economic Literature 40(2): 402-435.

Gagliarducci, Stefano. 2005. The dynamics of repeated temporary jobs. In: Labour Economics 12: $429-448$.

Georgellis, Yannis, Elisabetta Iossa, and Vurain Tabvuma. 2011. Crowding Out Intrinsic Motivation in the Public Sector. In: Journal of Public Administration Research and Theory 21(3): 473-493.

Grant, Adam M., and Sharon K. Parker. 2009. Redesigning Work Design Theories: The Rise of Relational and Proactive Perspectives. In: Academy of Management Annals 3(1): 317-375. 
Hackman, J. Richard, and Greg R. Oldham. 1975. Development of the job diagnostic survey. In: Journal of Applied Psychology 60(2): 159-170.

Heinrich, Carolyn J., Peter R. Mueser, and Kenneth R. Troske. 2005. Welfare to temporary work: Implications for labor market outcomes. In: Review of Economics and Statistics 87(1): 154-173.

Hirsch, Barry T. 2005. Why Do Part-Time Workers Earn Less? The Role of Worker and Job Skills. In: Industrial and Labor Relations Review 58(4): 525-551.

Houston, David J. 2000. Public-Service Motivation: A Multivariate Test. In: Journal of Public Administration Research and Theory 10(4): 713-727.

Houston, David J. 2006. "Walking the Walk" of Public Service Motivation: Public Employees and Charitable Gifts of Time, Blood, and Money. In: Journal of Public Administration Research and Theory 16(1): 67-86.

Houston, David J. 2011. Implications of occupational locus and focus for public service motivation: Attitudes toward work motives across nations. In: Public Administration Review 71(5): 761-771.

Jalonen, Paivi, Marianna Virtanen, Jussi Vahtera, Marko Elovainio, and Mika Kivimaki. 2006. Predictors of sustained organizational commitment among nurses with temporary job contracts. In: Journal of Nursing Administration 36(5): 268-276.

Jimeno, Juan F., and Luis Toharia. 1993. The effects of fixed-term employment on wages: Theory and evidence from Spain. In: Investigaciones Económicas 17(3): 475-494.

Kalleberg, Arne L. 2000. Nonstandard Employment Relations: Part-Time, Temporary and Contract Work. In: Annual Review of Sociology 26: 341-365.

Kalleberg, Arne L., Barbara F. Reskin, and Ken Hudson. 2000. Bad jobs in America:

Standard and nonstandard employment relations and job quality in the United States. In: American Sociological Review 65(2): 256-278.

Kim, Sangmook. 2008. Revising Perry's measurement scale of public service motivation. In: American Review of Public Administration 39(2): 149-163.

Kim, Sangmook, , Bradley E. Wright, Lotte Bøgh Andersen, Francesco Paolo Cerase, Robert K. Christensen, Céline Desmarais, Maria Koumenta, Peter Leisink, Bangcheng Liu, Jolanta Palidauskaite, Lene Holm Pedersen, James L. Perry, Adrian Ritz, Jeannette Taylor, and Paola De Vivo. 2013. Investigating the Structure and Meaning of Public Service Motivation across Populations: Developing an International Instrument and Addressing Issues of Measurement Invariance. In: Journal of Public Administration Research and Theory 23(1): 79-102.

Kjeldsen, Anne Mette, and Christian Bøtcher Jacobson. 2012. Public Service Motivation and Employment Sector: Attraction or Socialization. In: Journal of Public Administration Research and Theory 22(4): 899-926.

Kroll, Alexander, and Dominik Vogel. 2013. Prosocial attitudes in the public and private sector: Exploring behavioral effects and variation across time. In: SOEPpapers on Multidisciplinary Panel Data Research, No. 578. 
Leete, Laura. 2000. Wage equity and employee motivation in nonprofit and for-profit organizations. In: Journal of Economics Behavior \& Organization 43: 423-446.

Leisink, Peter, and Bram Steijn. 2008. Recruitment, Attraction, and Selection. In: Motivation in Public Management: 118-135.

Lewis, Gregory B., and Sue A. Frank. 2002. Who wants to work for the government? In: Public Administration Review 62(4): 395-404.

Lucas, Richard E. 2007. Adaptation and the Set-Point Model of subjective well-being: Does happiness change after major life events? In: Current Directions in Psychological Science 16(2): 75-79.

Mayer, Gerald. 2014. Selected Characteristics of Private and Public Sector Workers. In: Congressional Research Service 7-7500, R41897.

Mocan, H. Naci, and Erdal Tekin. 2003. Nonprofit sector and part-time work: An analysis of employer-employee matched data on child care workers. In: Review of Economics and Statistics 85(1): 38-50.

Moynihan, Donald P. 2012 Identifying the Antecedents to Government Performance: Implications for Human Resource Management. In: Handbook of Public Administration, London: Sage (2): 71-86.

Moynihan, Donald P., and Pandey, Sanjay K. 2007. Finding Workable Levers Over Work Motivation: Comparing Job Satisfaction, Job Involvement, and Organizational Commitment. In: Administration \& Society 39(7): 803-832.

Moynihan, Donald P., Wouter Vandenabeele, and Jens Blom-Hansen. 2013. Debate: Advancing public service motivation research. Public Money \& Management 33(4): 288-289.

OECD. 2002. Employment outlook. Chapter 3: Taking the measures of temporary employment. (http://www.oecd.org/employment/emp/17652675.pdf).

OECD. 2013. Incidence of involuntary part time workers. (http://stats.oecd.org/Index.aspx?DataSetCode=INVPT_I).

OECD. 2014. Online OECD Employment database.

(http://www.oecd.org/els/emp/onlineoecdemploymentdatabase.htm).

Oldham, Greg R., and J. Richard Hackman. 1981. Relationships between organizational structure and employee reactions: Comparing alternative frameworks. In: Administrative Science Quarterly 26(1): 66-83.

O’Neill, Bonnie, and Monica Adya. 2007. Knowledge sharing and the psychological contract: Managing knowledge workers across different stages of employment. In: Journal of Managerial Psychology 22(4): 411-436.

Pedersen, Mogens Jin. 2013. Public Service Motivation and Attraction to Public Versus Private Sector Employment: Academic Field of Study as Moderator?. In: International Public Management Journal 16(3): 357-385. 
Perry, James L., and Lois Recascino Wise. 1990. The Motivational Bases of Public Service. In: Public Administration Review 50(3): 367-373.

Perry, James L., and Hondeghem, Annie. 2008a. Directions for future theory and research. In: Motivation in Public Management: 294-314.

Perry, James L., and Annie Hondeghem. 2008b. Building theory and empirical evidence about public service motivation. In: International public management journal 11(1): 3-12.

Perry, James L., Annie Hondeghem, and Lois Recascino Wise. 2010. Revisiting the motivational bases of public service: Twenty years of research and an agenda for the future. In: Public Administration Review70(5): 681-690.

Potipiroon, Wisanupong, and Michael T. Ford. 2014. When Does Public Service Motivation Relate to Organizational Commitment? A Three-Way Interaction." Academy of Management Proceedings. No. 1. Academy of Management.

Rainey, Hal G., and Paula Steinbauer. 1999. Galloping Elephants: Developing Elements of a Theory of Effective Government Organization. In: Journal of Public Administration Research and Theory 9(1): 1-32.

Ritz, Adrian. 2011. Attraction to Public Policy Making: A Qualitative Inquiry into Improvements in PSM Measurement. In: Public Administration 89(3): 1128-1147.

Stamper, Christina L., Suzanne S. Masterson. 2002. Insider or outsider? How employee perceptions of insider status affect their work behavior. In: Journal of Organizational Behavior 23(8): 875-894.

Steijn, Bram. 2008. Person-Environment fit and public service motivation. In: International Public Management Journal 11(1): 13-27.

Summers, Clyde W. 1997. Contigent employment in the United States. In: Comparative Labor Law \& Policy Journal 18(4): 503-522.

Taylor, Jeannette. 2007. The Impact of Public Service Motives on Work Outcomes in Australia: A Comparative Multi-Dimensional Analysis. In: Public administration 85(4): 931-959.

Thorsteinson, Todd J. 2003. Job attitudes of part-time vs. full-time workers: A meta-analytic review. In: Journal of Occupational and Organizational Psychology 76(2): 151-177.

Tschirhart, Mary, Kira Kristal Reed, Sarah J. Freeman, Alison Louie Anker. 2008. Is the Grass Greener? Sector shifting and choice of sector by MPA and MBA Graduates. In: Nonprofit and Voluntary Sector Quarterly 37(4): 668-688.

Vandenabeele, Wouter. 2008. Government calling: Public service motivation as an element in selecting government as an employer of choice. In: Public Administration 86(4): 10891105 .

Vandenabeele, Wouter. 2009. The mediating effect of job satisfaction and organizational commitment on self-reported performance. In: International Review of Administrative Sciences 75(1): 11-34. 
Von Hippel, Courtney, Stephen L. Mangum, David B. Greenberger, Robert L. Heneman, and Jeffrey D. Skoglind. 1997. Temporary employment: Can organizations and employees both win? In. Academy of Management Perspectives 11(1): 93-104.

Walsh, Janet. 1999. Myths and counter-myths: an analysis of part-time female employees and their orientations to work and working hours. In: Work, Employment \& Society 13(2): 179-203.

Walsh, Janet. 2007. Experiencing Part-Time Work: Temporal tensions, social relations and the Work-Family interface. In: British Journal of Industrial Relations 45(1): 155-177.

Wagner, Gert G., Joachim R. Frick, and Jürgen Schupp. 2007. The German Socio-Economic Panel Study (SOEP) - Scope, Evolution and Enhancements. In: Schmollers Jahrbuch 127 (1): 139-169.

Wright, Bradley E., and Robert K. Christensen. 2010. Public Service Motivation: A Test of the Job Attraction-Selection-Attrition Model. In: International Public Management Journal 13(2): 155-176. 
Figures

Figure 1: Distribution of engagement for others and political/social involvement

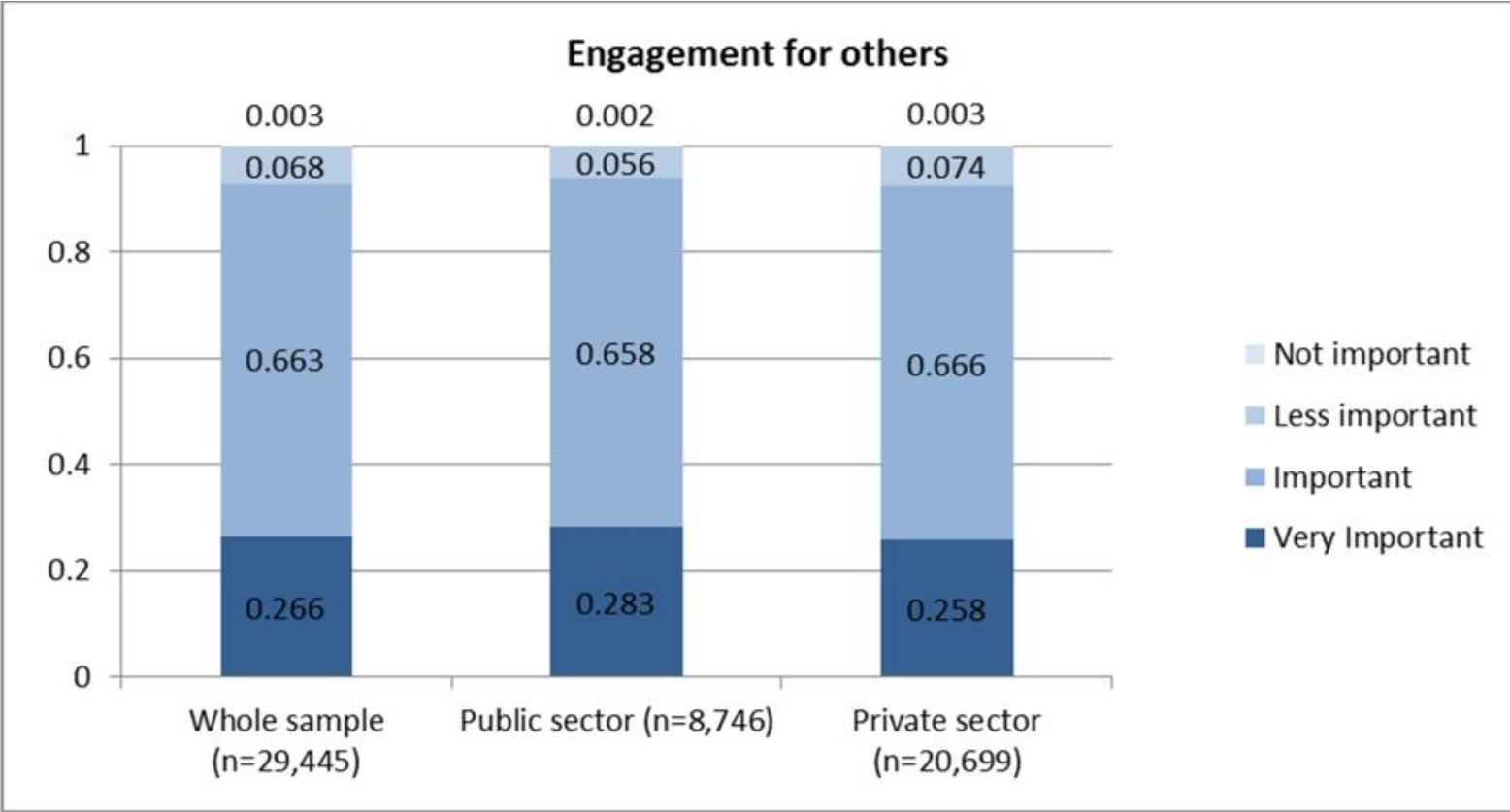

Political/Social Involvement

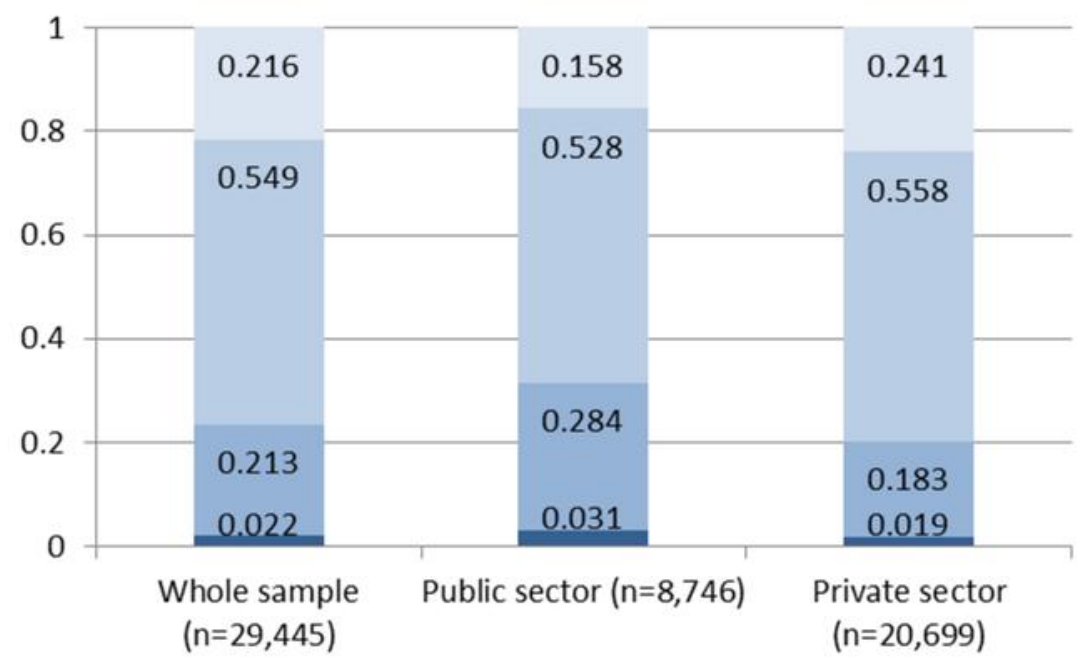

Not important

= Less important

= Important

- Very Important

$(n=29,445)$

$(n=20,699)$ 
Figure 2: Changes in PSM dimensions by sector changes

$\Delta$ Engagement for others

0,05

$-0,05$

\section{$\underline{\Delta \text { Political/social involvement }}$}

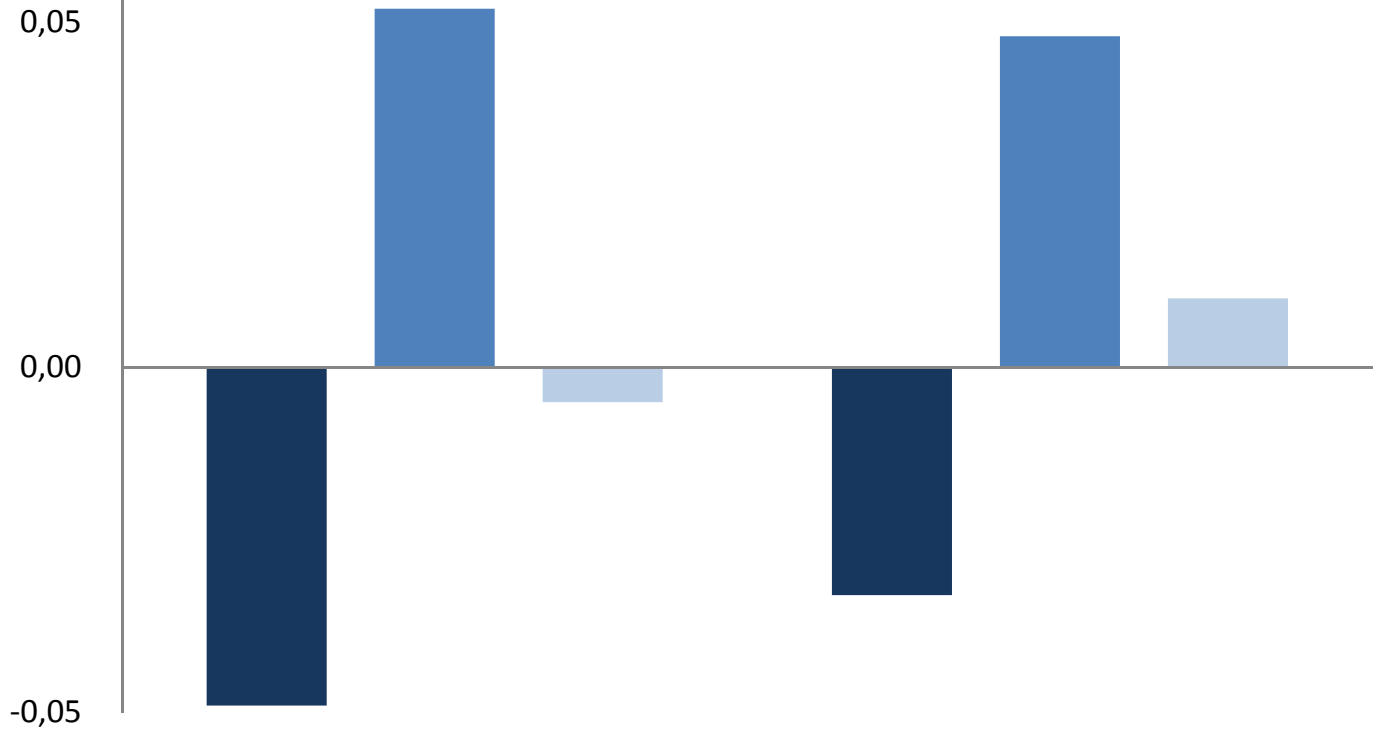

- Public to private $(\mathrm{N}=489) \quad$ Private to public $(\mathrm{N}=442) \square$ No change of sector $(\mathrm{N}=10,527)$ 
Figure 3: Changes in PSM dimensions by changes in contract types
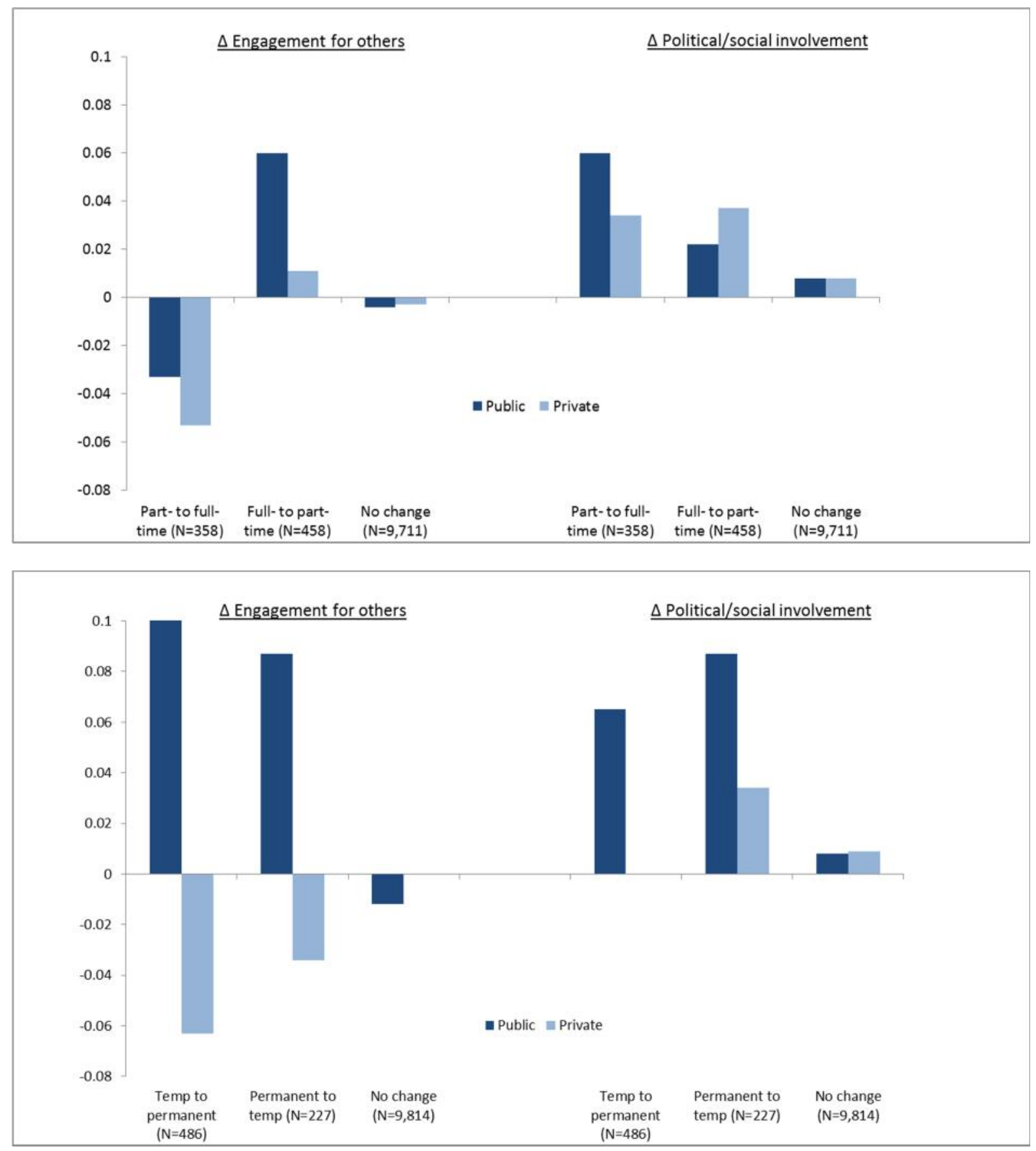
Tables

Table 1: Descriptive Statistics of other variables

\begin{tabular}{|c|c|c|c|c|c|c|}
\hline & \multicolumn{2}{|c|}{$\begin{array}{c}\text { Whole sample } \\
(n=29.445)\end{array}$} & \multicolumn{2}{|c|}{$\begin{array}{c}\text { Public sector } \\
(n=8.746)\end{array}$} & \multicolumn{2}{|c|}{$\begin{array}{c}\text { Private sector } \\
(n=20.699)\end{array}$} \\
\hline & mean & sd & mean & Sd & mean & sd \\
\hline \multicolumn{7}{|l|}{ Contract type } \\
\hline $\begin{array}{l}\text { Temporary } \\
\text { (1=yes) }\end{array}$ & 0.085 & & 0.105 & & 0.076 & \\
\hline $\begin{array}{l}\text { Part-time } \\
\text { (1=yes) }\end{array}$ & 0.210 & & 0.259 & & 0.189 & \\
\hline \multicolumn{7}{|l|}{ Demographics } \\
\hline $\operatorname{Sex}(1=$ male $)$ & 0.537 & & 0.427 & & 0.583 & \\
\hline Age (years) & 42.77 & 10.67 & 44.61 & 10.49 & 41.98 & 10.65 \\
\hline Schooling (years) & 12.66 & 2.701 & 13.52 & 2.926 & 12.30 & 2.514 \\
\hline Children (1=yes) & 0.367 & & 0.343 & & 0.377 & \\
\hline $\begin{array}{l}\text { Non-German } \\
\text { nationals }(1=\text { yes })\end{array}$ & 0.052 & & 0.026 & & 0.064 & \\
\hline $\begin{array}{l}\text { Eastern Germany } \\
(1=\text { yes })\end{array}$ & 0.275 & & 0.298 & & 0.265 & \\
\hline \multicolumn{7}{|l|}{ Health status } \\
\hline Very good & 0.098 & & 0.096 & & 0.098 & \\
\hline Good & 0.484 & & 0.473 & & 0.489 & \\
\hline Satisfactory & 0.313 & & 0.319 & & 0.310 & \\
\hline Poor & 0.094 & & 0.100 & & 0.091 & \\
\hline $\mathrm{Bad}$ & 0.012 & & 0.012 & & 0.012 & \\
\hline \multicolumn{7}{|l|}{$\underline{\text { Year }}$} \\
\hline 1995 & 0.182 & & 0.188 & & 0.179 & \\
\hline 2004 & 0.289 & & 0.291 & & 0.289 & \\
\hline 2008 & 0.257 & & 0.251 & & 0.259 & \\
\hline 2012 & 0.272 & & 0.270 & & 0.274 & \\
\hline
\end{tabular}


Table 2: Random effects ordered probit estimations on PSM characteristics

\begin{tabular}{|c|c|c|c|c|}
\hline & \multicolumn{2}{|c|}{ Engagement for others } & \multicolumn{2}{|c|}{ Political/social involvement } \\
\hline & (1) & (2) & (3) & (4) \\
\hline Public sector (1=yes) & $\begin{array}{c}0.086^{* * *} * \\
(0.022)\end{array}$ & $\begin{array}{c}0.104 * * * \\
(0.026)\end{array}$ & $\begin{array}{c}0.277 * * * \\
(0.023)\end{array}$ & $\begin{array}{c}0.305^{* * *} * \\
(0.027)\end{array}$ \\
\hline Temporary contract ( $1=$ yes) & $\begin{array}{c}0.046 \\
(0.035)\end{array}$ & $\begin{array}{c}0.098 * * \\
(0.041)\end{array}$ & $\begin{array}{c}0.107 * * * \\
(0.034)\end{array}$ & $\begin{array}{c}0.111 * * * \\
(0.042)\end{array}$ \\
\hline Part-time contract (1=yes) & $\begin{array}{c}0.069 * * \\
(0.027)\end{array}$ & $\begin{array}{c}0.072 * * \\
(0.040)\end{array}$ & $\begin{array}{c}0.089 * * * \\
(0.028)\end{array}$ & $\begin{array}{c}0.128 * * * \\
(0.033)\end{array}$ \\
\hline Public sector * Temporary & & $\begin{array}{c}-0.154 * * \\
(0.072)\end{array}$ & & $\begin{array}{l}-0.013 \\
(0.067) \\
\end{array}$ \\
\hline Public sector * Part-time & & $\begin{array}{l}-0.007 \\
(0.049)\end{array}$ & & $\begin{array}{c}-0.107 * * \\
(0.048)\end{array}$ \\
\hline Sex $(1=$ male $)$ & $\begin{array}{c}-0.450 * * * \\
(0.024)\end{array}$ & $\begin{array}{c}-0.449 * * * \\
(0.025)\end{array}$ & $\begin{array}{c}0.167 * * * \\
(0.025)\end{array}$ & $\begin{array}{c}0.170 * * * \\
(0.025)\end{array}$ \\
\hline Schooling (years) & $\begin{array}{c}0.012 * * * \\
(0.004)\end{array}$ & $\begin{array}{c}0.013 * * * \\
(0.004)\end{array}$ & $\begin{array}{c}0.129 * * * \\
(0.004)\end{array}$ & $\begin{array}{c}0.129 * * * \\
(0.004)\end{array}$ \\
\hline Age (years & $\begin{array}{c}-0.013 * * * \\
(0.001)\end{array}$ & $\begin{array}{c}-0.014 * * * * \\
(0.001)\end{array}$ & $\begin{array}{c}0.010 * * * \\
(0.001)\end{array}$ & $\begin{array}{c}0.010 * * * \\
(0.001)\end{array}$ \\
\hline Children (1=yes) & $\begin{array}{c}0.090^{* * *} * \\
(0.020)\end{array}$ & $\begin{array}{c}0.089 * * * \\
(0.020)\end{array}$ & $\begin{array}{c}-0.010 \\
(0.020) \\
\end{array}$ & $\begin{array}{l}-0.010 \\
(0.020) \\
\end{array}$ \\
\hline Non-German nationals (1=yes) & $\begin{array}{c}0.097 * * \\
(0.049)\end{array}$ & $\begin{array}{c}0.100^{* *} \\
(0.049)\end{array}$ & $\begin{array}{c}-0.270 * * * \\
(0.052)\end{array}$ & $\begin{array}{c}-0.269 * * * \\
(0.052)\end{array}$ \\
\hline Eastern Germany (1=yes) & $\begin{array}{c}-0.118 * * * \\
(0.023) \\
\end{array}$ & $\begin{array}{c}-0.118 * * * \\
(0.023)\end{array}$ & $\begin{array}{c}-0.151 * * * \\
(0.024)\end{array}$ & $\begin{array}{c}-0.151 * * * \\
(0.024)\end{array}$ \\
\hline Health status (5 dummies) & yes & Yes & Yes & yes \\
\hline Year (4 dummies) & yes & Yes & Yes & yes \\
\hline Number of observations & 29,445 & 29,445 & 29,445 & 29,445 \\
\hline
\end{tabular}

Notes: Robust standard errors in parentheses. $* * * \mathrm{p}<0.01, * * \mathrm{p}<0.05, * \mathrm{p}<0.1$. 
Table 3: Industry Differences within the public sector (Random effects ordered probit)

\begin{tabular}{|c|c|c|}
\hline & Engagement for others & Political/social involvement \\
\hline & (1) & (2) \\
\hline Temporary contract ( $1=$ yes $)$ & $\begin{array}{l}-0.058 \\
(0.068)\end{array}$ & $\begin{array}{l}0.115^{*} \\
(0.065)\end{array}$ \\
\hline Part-time contract ( $1=y e s)$ & $\begin{array}{c}0.015 \\
(0.049)\end{array}$ & $\begin{array}{l}-0.006 \\
(0.049)\end{array}$ \\
\hline $\operatorname{Sex}(1=$ male $)$ & $\begin{array}{c}-0.438 * * * \\
(0.047)\end{array}$ & $\begin{array}{c}0.223 * * * \\
(0.050)\end{array}$ \\
\hline Schooling (years) & $\begin{array}{c}0.011 \\
(0.008)\end{array}$ & $\begin{array}{c}0.139 * * * \\
(0.009)\end{array}$ \\
\hline Age (years) & $\begin{array}{c}-0.014 * * * \\
(0.002)\end{array}$ & $\begin{array}{c}0.010^{* * * *} \\
(0.002)\end{array}$ \\
\hline Children (1=yes) & $\begin{array}{c}0.112 * * * \\
(0.041)\end{array}$ & $\begin{array}{c}0.027 \\
(0.042)\end{array}$ \\
\hline Non-German nationals ( $1=y e s)$ & $\begin{array}{l}-0.024 \\
(0.123)\end{array}$ & $\begin{array}{c}-0.370 * * \\
(0.167)\end{array}$ \\
\hline Eastern Germany (1=yes) & $\begin{array}{c}-0.107 * * \\
(0.044)\end{array}$ & $\begin{array}{c}-0.205^{* * *} * \\
(0.047)\end{array}$ \\
\hline Industry (base category: health) & & \\
\hline Finance & $\begin{array}{c}-0.299 * * * \\
(0.094)\end{array}$ & $\begin{array}{l}-0.015 \\
(0.103)\end{array}$ \\
\hline Education & $\begin{array}{c}0.020 \\
(0.060)\end{array}$ & $\begin{array}{c}0.143^{* *} \\
(0.064)\end{array}$ \\
\hline Public administration & $\begin{array}{c}-0.149 * * * \\
(0.053)\end{array}$ & $\begin{array}{c}0.066 \\
(0.058)\end{array}$ \\
\hline Culture \& sports & $\begin{array}{c}-0.250 * \\
(0.130)\end{array}$ & $\begin{array}{c}0.345^{* *} \\
(0.152)\end{array}$ \\
\hline Transport \& utilities & $\begin{array}{c}-0.171 * * \\
(0.081)\end{array}$ & $\begin{array}{l}-0.077 \\
(0.088)\end{array}$ \\
\hline Health status (5 dummies) & yes & Yes \\
\hline Year (4 dummies) & yes & Yes \\
\hline Number of observations & 7,851 & 7,851 \\
\hline
\end{tabular}

Notes: Robust standard errors in parentheses. $* * * \mathrm{p}<0.01, * * \mathrm{p}<0.05, * \mathrm{p}<0.1$ 
Table 4: Job differences within health and education - Random effects ordered

\begin{tabular}{|l|c|c|c|c|}
\hline & \multicolumn{2}{|c|}{ Health } & \multicolumn{2}{c|}{ Education } \\
\hline & $\begin{array}{c}\text { Engagement } \\
\text { for others }\end{array}$ & $\begin{array}{c}\text { Political/social } \\
\text { involvement }\end{array}$ & $\begin{array}{c}\text { Engagement } \\
\text { for others }\end{array}$ & $\begin{array}{c}\text { Political/social } \\
\text { involvement }\end{array}$ \\
\hline Core of industry (1=yes) & $0.194^{* *}$ & 0.055 & -0.085 & 0.026 \\
& $(0.079)$ & $(0.087)$ & $(0.109)$ & $(0.112)$ \\
\hline Temporary contract & -0.029 & -0.121 & -0.198 & 0.134 \\
$(1=$ yes) & $(0.116)$ & $(0.111)$ & $(0.140)$ & $(0.131)$ \\
\hline Part-time contract (1=yes) & $0.144^{*}$ & 0.119 & -0.048 & -0.108 \\
& $(0.085)$ & $(0.086)$ & $(0.093)$ & $(0.087)$ \\
\hline Sex (1=male) & $-0.182^{*}$ & $0.357^{* * *}$ & $-0.610^{* * *}$ & $0.257^{* *}$ \\
& $(0.097)$ & $(0.106)$ & $(0.105)$ & $(0.108)$ \\
\hline Schooling (years) & -0.012 & $0.170^{* * *}$ & 0.026 & $0.133^{* * *}$ \\
& $(0.016)$ & $(0.019)$ & $(0.017)$ & $(0.019)$ \\
\hline Age (years) & $-0.015^{* * *}$ & 0.001 & $-0.017 * * *$ & $0.013^{* *}$ \\
& $(0.004)$ & $(0.004)$ & $(0.004)$ & $(0.005)$ \\
\hline Children (1=yes) & -0.029 & $-0.186^{* *}$ & $0.182^{* *}$ & 0.111 \\
& $(0.077)$ & $(0.084)$ & $(0.088)$ & $(0.087)$ \\
\hline Non-German nationals & 0.086 & $-0.572^{* *}$ & -0.272 & -0.295 \\
$(1=y e s)$ & $(0.173)$ & $(0.248)$ & $(0.341)$ & $(0.388)$ \\
\hline Eastern Germany (1=yes) & $-0.154^{*}$ & $-0.201 * *$ & $-0.200^{* *}$ & $-0.268^{* * *}$ \\
& $(0.086)$ & $(0.094)$ & $(0.088)$ & $(0.097)$ \\
\hline Health status (5 dummies) & yes & yes & yes & yes \\
\hline Year (4 dummies) & yes & yes & yes & yes \\
\hline Number of observations & 1,891 & 1,891 & 2,103 & 2,103 \\
\hline & & & & \\
\hline
\end{tabular}

Notes: Robust standard errors in parentheses. ${ }^{* * *} \mathrm{p}<0.01,{ }^{*} \mathrm{p}<0.05,{ }^{*} \mathrm{p}<0.1$. 


\section{Appendix}

Figure A: Industry specific distribution of PSM characteristics within the public sector
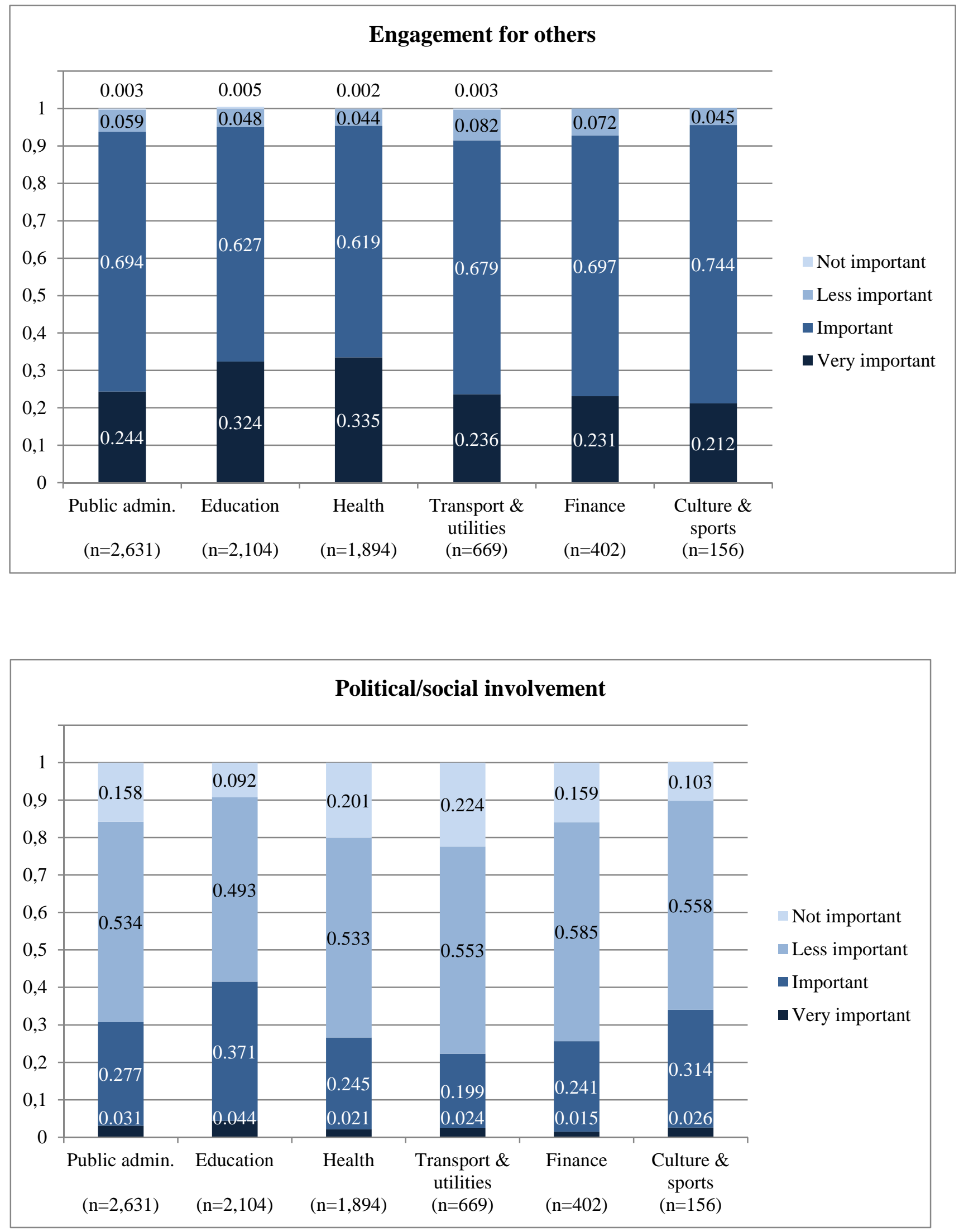
Figure B: Job differences within health care and education - Descriptives
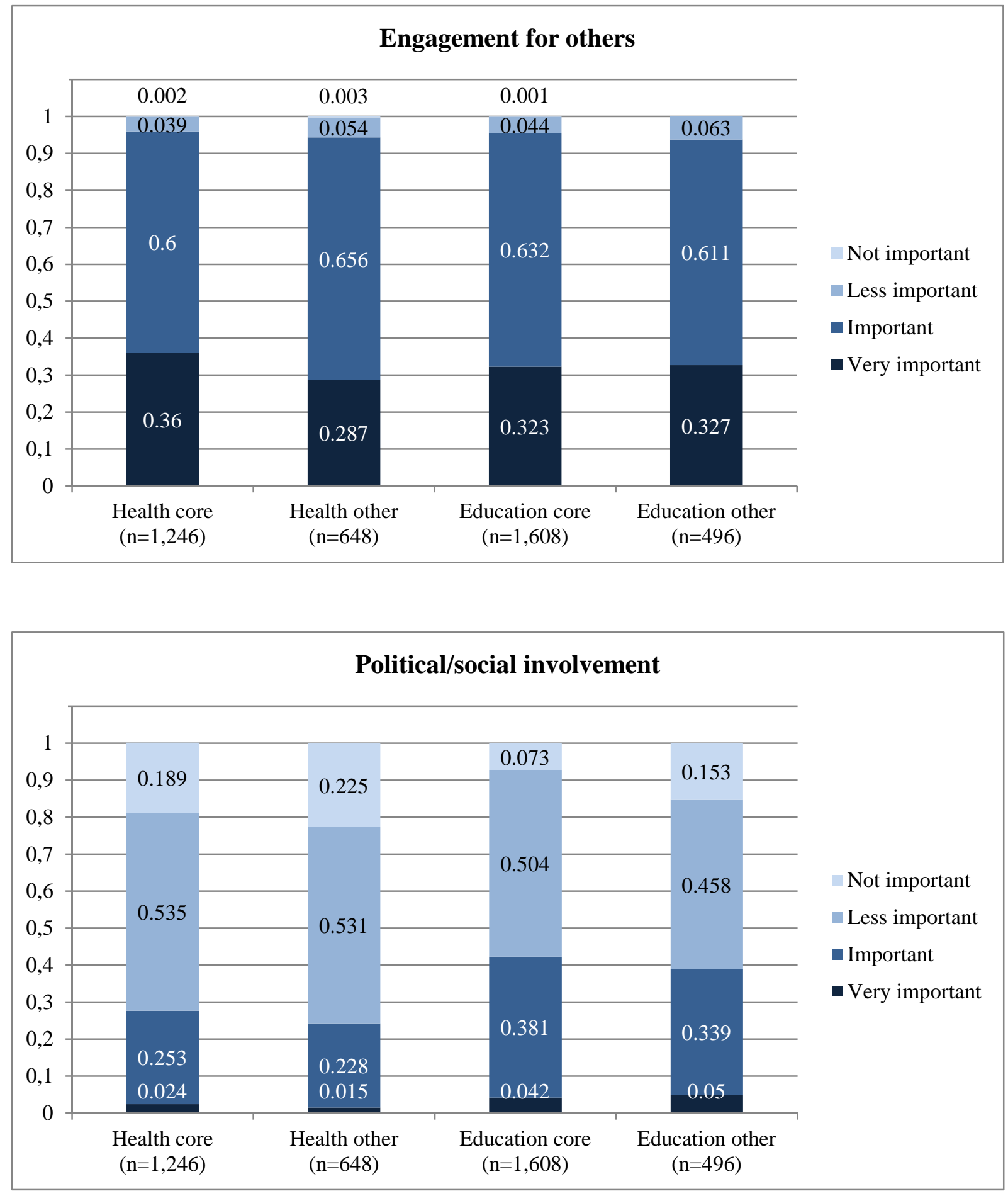
Table A: Fixed effects estimations on PSM characteristics

\begin{tabular}{|l|c|c|c|c|}
\hline & \multicolumn{2}{|c|}{ Engagement for others } & \multicolumn{2}{c|}{ Political/social involvement } \\
\hline & $(\mathbf{1})$ & $\mathbf{( 2 )}$ & $\mathbf{( 3 )}$ & $\mathbf{( 4 )}$ \\
\hline Public sector (1=yes) & $0.039^{* *}$ & $0.041^{*}$ & 0.026 & 0.022 \\
& $(0.019)$ & $(0.022)$ & $(0.022)$ & $(0.025)$ \\
\hline Temporary contract (1=yes) & -0.020 & -0.002 & 0.004 & -0.001 \\
& $(0.020)$ & $(0.024)$ & $(0.023)$ & $(0.027)$ \\
\hline Part-time contract (1=yes) & $0.040^{* *}$ & 0.027 & 0.010 & 0.008 \\
& $(0.018)$ & $(0.022)$ & $(0.021)$ & $(0.026)$ \\
\hline Public sector * Temporary & & $-0.068^{*}$ & & 0.017 \\
& & $(0.041)$ & & $(0.047)$ \\
\hline Public sector * Part-time & & 0.033 & & 0.003 \\
& & $(0.031)$ & & $(0.036)$ \\
\hline Sex (1=male) & --- & --- & --- & -- \\
\hline Schooling (years) & & & & $0.020^{*}$ \\
& 0.007 & 0.006 & $0.020^{*}$ & $(0.010)$ \\
\hline Age (years) & $(0.009)$ & $(0.009)$ & $(0.010)$ & $0.010^{* * *}$ \\
& $-0.003^{* * *}$ & $-0.003 * * *$ & $0.010^{* * *}$ & $(0.001)$ \\
\hline Children (1=yes) & $(0.001)$ & $(0.001)$ & $(0.001)$ & -0.017 \\
& 0.008 & 0.008 & -0.017 & $(0.013)$ \\
\hline Non-German nationals (1=yes) & $(0.012)$ & $(0.012)$ & $(0.013)$ & -0.129 \\
& 0.014 & 0.015 & -0.128 & $(0.106)$ \\
\hline Eastern Germany (1=yes) & $(0.092)$ & $(0.092)$ & $(0.106)$ & -0.065 \\
& $-0.117^{* *}$ & $-0.117^{* *}$ & -0.064 & $(0.064)$ \\
\hline Health status (5 dummies) & $(0.056)$ & $(0.056)$ & $(0.064)$ & yes \\
\hline Year (4 dummies) & yes & yes & yes & yes \\
\hline Number of observations & yes & yes & yes & 29,445 \\
\hline & 29,445 & 29,445 & 29,445 & \\
\hline
\end{tabular}

Notes: Robust standard errors in parentheses. $* * * \mathrm{p}<0.01, * * \mathrm{p}<0.05, * \mathrm{p}<0.1$. 